\title{
JARAK TANAM BERBEDA PADA UJI DAYA HASIL LIMA VARIETAS JAGUNG HIBRIDA
}

\author{
Putri Dewangga Maharani ${ }^{1}$, Ahmad Yunus $^{2)}$, Dwi Harjoko ${ }^{2)}$ \\ 1) Mahasiswa Program Studi Agroteknologi Fakultas Pertanian UNS, Surakarta \\ 2) Staf Pengajar Program Studi Agroteknologi Fakultas Pertanian UNS, Surakarta \\ Author contact: yunus.uns7@gmail.com
}

\begin{abstract}
Maize (Zea mays L.) is the second most important cereal crop of Indonesia after rice. The productivity of corn in Central Java province in 2015 was increased that considered as relatively low. Maize productivitiy needs to be improved to supply the requirement of people through of plant spacing and use the hybrid maize varieties. The aims of study was to determine the effectiveness level of plant spacing, to test the best hybrid maize varieties, and test the combination of two treatments to optimize the yield potential hybrid maize. This study has been conducted from June until October 2017, at Desa Srimartani, Kecamatan Piyungan, Kabupaten Bantul, Daerah Istimewa Yogyakarta. This study was arranged in Split Plot Design consisting of two factors that have been researched, varieties (ABCD, EFGH, NK6172, P27 and DK77) and plant spacing $(70 \times 20 \mathrm{~cm}, 75 \times 20 \mathrm{~cm}$, and $75 \times 25 \mathrm{~cm})$. The results show that treatment of varieties mostly can increase all of variable analysis but there is no interaction on both treatment except plant height, fresh and dry biomass weight. Variable of plant height, tasseling and silking, cob weight with husk, cob weight without husk, kernel seeds weight per plot, 100 seeds weight, yields per hectare show that the highest average is variety of P27. While treatment of plant spacing has no effect because the interval between treatments plant spacing is too close therefore it shows insignificantly different result. The highest dry kernel product on variety treatment P27 $\left(8,82\right.$ ton ha $\left.^{-1}\right)$, followed by DK77 $\left(8,53\right.$ ton ha $\left.{ }^{-1}\right), A B C D\left(8,50\right.$ ton ha $\left.{ }^{1}\right)$, NK6172 (8,34 ton ha $\left.{ }^{-1}\right)$, and EFGH $\left(7,13\right.$ ton ha $\left.{ }^{-1}\right)$.
\end{abstract}

Keywords: Plant Density, Superior Seeds, Productivity

AGROTECHNOLOGY RESEARCH JOURNAL

Maharani PD, Yunus A, Harjoko D. 2018. Jarak tanam berbeda pada uji daya hasil lima varietas jagung hibrida. Agrotech Res J 2(2): 52-57.

Maharani PD, Yunus A, Harjoko D. 2018. The different plant spacing of the yield potential test of five hybrid maize varieties. Agrotech Res J 2(2): 52-57.

\section{PENDAHULUAN}

Jagung (Zea mays L.) merupakan tanaman pangan pokok kedua setelah padi di Indonesia. Pertambahan jumlah penduduk dan industri pangan menjadikan jagung dibutuhkan dalam jumlah besar. Produksi jagung provinsi Jawa Tengah tahun 2015 sebesar 3,21 juta ton pipilan kering atau meningkat sebanyak 0,16 juta ton $(1,05 \%)$ dibanding tahun 2014 . Peningkatan produksi terjadi karena peningkatan luas panen seluas 47 ha $(1,01 \%)$ dan produktivitas sebesar 2,47 kuintal ha $^{-1}(1,04 \%)$, dimana produktivitas tersebut masih tergolong rendah (BPS 2016). Produktivitas jagung rendah akibat pengolahan lahan kurang optimal, penerapan jarak tanam dan pemupukan kurang tepat, pengendalian hama, penyakit dan gulma kurang efisien, dan penggunaan benih varietas hibrida masih jarang.

Pemilihan varietas unggul jagung hibrida memiliki peran sangat penting untuk menentukan kualitas dan kuantitas produksi jagung yang akan dihasilkan. Setiap varietas memiliki karakter berbeda misal dari potensi hasil, ketahanan terhadap hama penyakit, ketahanan terhadap kekeringan, umur tanaman, umur panen, warna biji. Pemilihan varietas benih apabila diimbangi dengan penerapan jarak tanam yang tepat dapat meningkatkan produktivitas jagung hibrida optimal. Pengaturan kerapatan tanaman bertujuan untuk

${ }^{*}$ Fak. Pertanian UNS Surakarta

JI. Ir. Sutami 36 A Surakarta mengurangi persaingan antar tanaman, yaitu cahaya, ruang, dan nutrisi. Berdasarkan permasalah tersebut maka perlu dilakukan penelitian strategi penggunaan jarak tanam yang tepat dalam mengoptimalkan daya hasil jagung hibrida. Penelitian ini bertujuan untuk menentukan tingkat efektivitas jarak tanam dalam mengoptimalkan daya hasil jagung hibrida, mengkaji varietas jagung hibrida terbaik untuk pengoptimalan daya hasil jagung hibrida, dan mengkaji kombinasi kedua perlakuan dalam mengoptimalkan daya hasil jagung hibrida.

\section{BAHAN DAN METODE}

Penelitian dilaksanakan pada bulan Juni sampai Oktober 2017, bertempat di Desa Srimartani, Kecamatan Piyungan, Kabupaten Bantul, Daerah Istimewa Yogyakarta. Bahan yang digunakan meliputi benih jagung hibrida varietas ABCD, EFGH, NK6172, P27, DK77, pupuk urea, dan pupuk NPK. Peralatan yang digunakan berupa hand tractor, cangkul, sabit, tugal, timbangan analitik, dan meteran.

Penelitian menggunakan rancangan petak terpisah (Split Plot Design) yang terdiri dari 2 fakor yang diteliti, yaitu varietas (ABCD, EFGH, NK6172, P27 dan DK77) dan jarak tanam $(70 \times 20 \mathrm{~cm}, 75 \times 20 \mathrm{~cm}$, dan $75 \times 25$ $\mathrm{cm})$ dengan masing-masing 3 kali ulangan. Data hasil penelitian dianalisis ragam taraf $5 \%$, untuk mengetahui pengaruh varietas dan jarak tanam terhadap daya hasil jagung hibrida. Apabila hasil analisis ragam memberikan hasil beda nyata selanjutnya dilakukan 
Duncan's Multiple Range Test (DMRT) untuk mengetahui beda antar perlakuan.

\section{HASIL DAN PEMBAHASAN}

\section{Tinggi tanaman}

Perlakuan varietas dan jarak tanam mampu meningkatkan tinggi tanaman jagung hibrida yang diamati. Masing-masing perlakuan menunjukkan hasil yang beragam.

Tabel 1 Rata-rata tinggi tanaman jagung umur 10 MST pada lima varietas dan jarak tanam berbeda

\begin{tabular}{|c|c|c|c|c|c|}
\hline \multirow{2}{*}{$\begin{array}{l}\text { Jarak } \\
\text { Tanam(cm) }\end{array}$} & \multicolumn{5}{|c|}{ Varietas } \\
\hline & ABCD & EFGH & $\begin{array}{c}\mathrm{NK} \\
6172 \\
\end{array}$ & P27 & DK77 \\
\hline $70 \times 20$ & $\underset{a b c}{219,33}$ & $\begin{array}{l}229,00 \\
\text { abcd }\end{array}$ & $\underset{a b c}{216,22}$ & $\underset{c d}{241,50}$ & $\underset{\mathrm{abcd}}{227,00}$ \\
\hline $75 \times 20$ & $\begin{array}{l}224,50 \\
\mathrm{abc}\end{array}$ & $\begin{array}{l}231,56 \\
\text { bcd }\end{array}$ & ${ }_{a b}^{210,78}$ & $\begin{array}{l}235,55 \\
\text { bcd }\end{array}$ & $\begin{array}{l}226,61 \\
\text { abcd }\end{array}$ \\
\hline $75 \times 25$ & $\underset{\mathrm{abc}}{224,78}$ & ${ }_{b c d}^{232,61}$ & $\underset{\mathrm{abc}}{224,00}$ & $252,05^{d}$ & $202,78^{a}$ \\
\hline
\end{tabular}

Keterangan: Angka yang diikuti huruf sama menunjukkan tidak beda nyata berdasarkan DMRT taraf $5 \%$.

Varietas P27 dengan jarak tanam $75 \times 25 \mathrm{~cm}$ mampu meningkatkan tinggi tanaman dengan nilai ratarata sebesar 252,05 cm (Tabel 1). Hal ini dikarenakan masing-masing varietas memiliki faktor genetik berbeda-beda. Desyanto dan Herman (2014) juga menyatakan bahwa perlakuan varietas dipengaruhi oleh faktor genetik masing-masing varietas yang diuji. Penampilan pertumbuhan yang berbeda antar varietas jagung diduga disebabkan oleh adanya perbedaan kecepatan pembelahan, perbanyakan dan pembesaran sel. Terlihat bahwa tinggi tanaman ABCD dan EFGH dengan jarak tanam $75 \times 25 \mathrm{~cm}$ hampir mendekati tinggi tanaman varietas P27 dan lebih tinggi dari varietas NK6172 dan DK77.

\section{Tasseling dan silking}

Fase vegetatif jagung berakhir ditandai dengan bunga jantan muncul pada ujung jagung dan peristiwa ini merupakan awal dimulainya fase generatif. Pengamatan umur muncul tassel dan silk merupakan pengamatan pertumbuhan jagung fase generatif. Perlakuan varietas saja yang mampu mempercepat tasseling dan silking.

Tabel 2 Rata-rata umur muncul tassel dan silk jagung hibrida pada lima varietas jagung hibrida

\begin{tabular}{lccccc}
\hline \multirow{2}{*}{ Variabel } & \multicolumn{5}{c}{ Varietas } \\
\cline { 2 - 6 } & ABCD & EFGH & NK6172 & P27 & DK77 \\
\hline $\begin{array}{l}\text { Tasseling } \\
\text { (HST) }\end{array}$ & $54,21^{\mathrm{a}}$ & $53,74^{\mathrm{a}}$ & $55,52^{\mathrm{b}}$ & $53,21^{\mathrm{a}}$ & $55,46^{\mathrm{b}}$ \\
$\begin{array}{l}\text { Silking } \\
\text { (HST) }\end{array}$ & $58,01^{\mathrm{a}}$ & $58,21^{\mathrm{a}}$ & $61,64^{\mathrm{b}}$ & $57,79^{\mathrm{a}}$ & $62,14^{\mathrm{b}}$ \\
\hline
\end{tabular}

Keterangan : Angka yang diikuti huruf sama pada baris menunjukkan tidak beda nyata berdasarkan DMRT taraf $5 \%$.

Tabel 2 menunjukkan perlakuan varietas jagung hibrida mampu mempercepat muncul tassel dan silk. Varietas P27 memiliki umur tercepat tasseling dan silking yaitu berturut-turut selama 53,21 dan 57,79 hari setelah tanam (HST). Kecepatan umur muncul bunga jantan dan betina varietas $A B C D$ dan $E F G H$ menunjukkan hampir sama dengan varietas P27 serta lebih cepat dibanding dengan varietas NK6172 dan DK77 (Tabel 2). Waktu muncul bunga yang cepat akan mempengaruhi pengisian biji. Hal ini sesuai dengan pernyataan Jafri (2011) bahwa perbedaan antara umur masak pollen dan umur keluar rambut tongkol (silkdelay) berpengaruh terhadap pengisian biji tongkol. Semakin besar silkdelay semakin berkurang hasil yang didapat. Biji pada tongkol yang terisi cepat akan mempercepat waktu panen.

\section{Jumlah tanaman per plot}

Jumlah tanaman per plot berkaitan dengan kerapatan tanaman atau populasi tanaman. Variabel ini akan mempengaruhi pertumbuhan jagung juga produksi yang dihasilkan. Kerapatan tanaman dipengaruhi oleh perlakuan jarak tanam yang diterapkan.

Tabel 3 Rata-rata jumlah tanaman per satuan luas pada jarak tanam

\begin{tabular}{|c|c|c|c|}
\hline \multirow{2}{*}{ Variabel } & \multicolumn{3}{|c|}{ Jarak Tanam $(\mathrm{cm})$} \\
\hline & $70 \times 20 \mathrm{~cm}$ & $75 \times 20 \mathrm{~cm}$ & $75 \times 25 \mathrm{~cm}$ \\
\hline $\begin{array}{l}\text { Jumlah } \\
\text { tanaman per } \\
\text { satuan luas } \\
\text { (batang) }\end{array}$ & $41,00^{b}$ & $42,27^{b}$ & $35,47^{a}$ \\
\hline
\end{tabular}

Keterangan : Angka yang diikuti huruf sama pada baris menunjukkan tidak beda nyata berdasarkan DMRT taraf $5 \%$.

Jarak tanam $75 \times 25 \mathrm{~cm}$ memiliki jumlah tanaman terendah (Tabel 3). Hal ini dikarenakan jarak tanam yang lebar akan memberikan kerapatan yang lebar pula dengan jumlah tanaman yang sedikit. Menurut Jiang et al. (2013), penelitian yang membahas efek jarak tanam pada hasil, sebagian besar difokuskan pada peningkatan struktur kanopi di atas tanah yang menghasilkan pengingkatan laju fotosintesis melalui intersepsi efektif radiasi matahari. Didukung oleh Biswas et al. (2014) bahwa Jarak tanam memiliki pengaruh terhadap perkembangan kanopi yang akan mempengaruhi serapan cahaya matahari. Wahyudin et al. (2015) menambahkan bahwa jarak tanam secara langsung dapat mempengaruhi kerapatan populasi tanaman. Jarak tanam lebar akan memiliki populasi tanaman rendah, sedangkan jarak tanam sempit akan memiliki populasi tanaman tinggi. Populasi tanaman rendah lebih banyak menangkap cahaya matahari melalui kanopi tanaman.

\section{Bobot segar dan kering brangkasan}

Variabel pengamatan bobot segar brangkasan digunakan untuk mengetahui rendemen jagung. Bobot kering brangkasan digunakan untuk mengetahui asimilasi fotosintat yang dihasilkan suatu tanaman. Perlakuan varietas dan jarak tanam mampu meningkatkan kedua variabel ini.

Tabel 4 Rata-rata bobot segar brangkasan pada lima varietas dan jarak tanam berbeda (gram)

\begin{tabular}{cccccc}
\hline \multirow{2}{*}{$\begin{array}{c}\text { Jarak } \\
\text { Tanam }\end{array}$} & ABCD & EFGH & NK & P27 & DK77 \\
\cline { 2 - 5 } & & & 6172 \\
\hline $70 \times 20$ & $327,57^{\text {d }}$ & $278,37^{\text {ab }}$ & 297,33 & 283,20 & $264,93^{\text {a }}$ \\
\hline
\end{tabular}




\begin{tabular}{|c|c|c|c|c|c|}
\hline \multirow[b]{2}{*}{$\begin{array}{c}\text { Jarak } \\
\text { Tanam }\end{array}$} & \multicolumn{5}{|c|}{ Varietas } \\
\hline & ABCD & EFGH & $\begin{array}{c}\text { NK } \\
6172 \\
\end{array}$ & P27 & DK77 \\
\hline $\mathrm{cm}$ & & & & $\mathrm{abc}$ & \\
\hline $\begin{array}{c}75 \times 20 \\
\mathrm{~cm}\end{array}$ & $316,70^{d}$ & $322,57^{d}$ & $\underset{\mathrm{e}}{355,53}$ & $308,90^{\text {cd }}$ & $266,90^{\mathrm{ab}}$ \\
\hline $\begin{array}{c}75 \times 25 \\
\mathrm{~cm}\end{array}$ & $365,40^{\mathrm{e}}$ & $314,60^{d}$ & $\underset{\text { cd }}{308,27}$ & $325,40^{d}$ & $272,23^{a b}$ \\
\hline
\end{tabular}

Keterangan : Angka yang diikuti huruf sama menunjukkan tidak beda nyata berdasarkan DMRT taraf $5 \%$.

Rata-rata bobot segar brangkasan tertinggi yaitu varietas $A B C D$ dengan jarak tanam $75 \times 25 \mathrm{~cm}$ (Tabel 4). Hal ini diduga terdapat karakter genetik berbeda antar masing-masing varietas yang diteliti, selain itu dengan jarak tanam lebar maka persaingan antar tanaman dalam mendapatkan sinar matahari lebih kecil. Didukung oleh Enujeke (2013) bahwa jarak dalam baris yang meningkat akan mengurangi persaingan ruang antar tanaman, persaingan menyerap sinar matahari, dan nutrisi sehingga fotosintesis dapat berjalan optimal dan menghasilkan bobot segar brangkasan optimal pula.

Tabel 5 Rata-rata bobot kering brangkasan pada lima varietas dan jarak tanam berbeda (gram)

\begin{tabular}{|c|c|c|c|c|c|}
\hline \multirow[b]{2}{*}{$\begin{array}{l}\text { Jarak } \\
\text { Tanam }\end{array}$} & \multicolumn{5}{|c|}{ Varietas } \\
\hline & $A B C D$ & EFGH & $\begin{array}{c}\text { NK } \\
6172\end{array}$ & P27 & DK77 \\
\hline $\begin{array}{c}70 \times 20 \\
\mathrm{~cm}\end{array}$ & $218,37^{d}$ & $185,61^{\mathrm{ab}}$ & $19 \underset{b c d}{198,21}$ & $\underset{\mathrm{abc}}{188,83}$ & $176,64^{a}$ \\
\hline $\begin{array}{c}75 \times 20 \\
\mathrm{~cm}\end{array}$ & $211,15^{d}$ & $215,03^{d}$ & $\underset{\mathrm{e}}{237,02}$ & $205,92^{\mathrm{cd}}$ & $177,92^{\mathrm{ab}}$ \\
\hline $\begin{array}{c}75 \times 25 \\
\mathrm{~cm}\end{array}$ & $243,59^{\mathrm{e}}$ & $209,73^{d}$ & $\underset{\text { cd }}{205,53}$ & $216,92^{d}$ & $181,49^{\mathrm{ab}}$ \\
\hline
\end{tabular}

Keterangan : Angka yang diikuti huruf sama menunjukkan tidak beda nyata berdasarkan DMRT taraf $5 \%$.

Tabel 5 menunjukkan bahwa varietas ABCD dengan jarak tanam $75 \times 25 \mathrm{~cm}$ memiliki bobot kering brangkasan tertinggi (243,59 gram). Menurut Desyanto dan Herman (2014), diduga peningkatan bobot kering pada jarak tanam yang semakin lebar disebabkan terjadinya peningkatan proses fotosintesis, sehingga fotosintat yang dialokasikan ke seluruh organ tanaman bertambah. Hamidi et al. (2010) menambahkan bahwa populasi tanaman tinggi akan menyebabkan hasil biomassa menurun karena adanya persaingan antar tanaman sehingga kemampuan produksi individu tanaman terhambat.

\section{Bobot tongkol dengan kelobot dan tanpa kelobot}

Tongkol dengan pengisian biji optimal akan meningkatkan hasil. Perlakuan varietas jagung hibrida mampu meningkatkan bobot tongkol dengan kelobot dan tanpa kelobot, sedangkan jarak tanam tidak memberikan pengaruh terhadap bobot tongkol dengan kelobot dan tanpa kelobot.

Tabel 6 Rata-rata bobot tongkol jagung hibrida dengan dan tanpa kelobot pada varietas yang berbeda (gram)

\begin{tabular}{|c|c|c|c|c|c|}
\hline \multirow[b]{2}{*}{ Variabel } & \multicolumn{5}{|c|}{ Varietas } \\
\hline & $A B C D$ & EFGH & $\begin{array}{c}\text { NK } \\
6172\end{array}$ & P 27 & DK 77 \\
\hline $\begin{array}{l}\text { Berat } \\
\text { tongkol }\end{array}$ & $362,30^{a b}$ & $329,2^{a}$ & $318,8^{a}$ & $392,8^{b}$ & $342,11^{a}$ \\
\hline
\end{tabular}

\begin{tabular}{|c|c|c|c|c|c|}
\hline \multirow[b]{2}{*}{ Variabel } & \multicolumn{5}{|c|}{ Varietas } \\
\hline & $A B C D$ & EFGH & $\begin{array}{c}\text { NK } \\
6172\end{array}$ & P 27 & DK 77 \\
\hline $\begin{array}{l}\text { dengan } \\
\text { klobot } \\
\text { (gram) } \\
\text { Berat } \\
\text { Tongkol } \\
\text { tanpa } \\
\text { klobot } \\
\text { (gram) }\end{array}$ & $307,46^{\mathrm{ab}}$ & $277,8^{\mathrm{a}}$ & $272,2^{a}$ & $334,5^{\mathrm{b}}$ & $296,21^{\text {ab }}$ \\
\hline
\end{tabular}

Keterangan : Angka yang diikuti huruf sama pada baris menunjukkan tidak beda nyata berdasarkan DMRTtaraf $5 \%$.

Data pada Tabel 6 memberi informasi bahwa varietas $A B C D$ dan EFGH memiliki rata-rata bobot tongkol dengan kelobot dan tanpa kelobot yang masih rendah dibanding varietas P27 namun lebih unggul dari varietas lainnya. Hal ini dikarenakan jumlah biji pada tongkol varietas P27 lebih banyak. Khan et al. (2017) menambahkan bahwa peningkatan signifikan dalam pertumbuhan tanaman secara keseluruhan berdasarkan peningkatan efisiensi fotosintesis. Fotosintat optimal menghasilkan peningkatan hasil tanaman, panjang tongkol dan berat tongkol didukung dengan tingkat kesuburan lingkungan.

Tabel 7 Rata-rata bobot tongkol jagung hibrida dengan dan tanpa kelobot pada jarak tanam

\begin{tabular}{lccc}
\hline \multicolumn{1}{c}{ Variabel } & \multicolumn{3}{c}{ Jarak Tanam } \\
\cline { 2 - 4 } & $70 \times 20 \mathrm{~cm}$ & $75 \times 20 \mathrm{~cm}$ & $75 \times 25 \mathrm{~cm}$ \\
\hline $\begin{array}{l}\text { Bobot tongkol } \\
\text { dengan klobot } \\
\text { (gram) }\end{array}$ & $332,74^{\mathrm{a}}$ & $353,96^{\mathrm{a}}$ & $360,48^{\mathrm{a}}$ \\
$\begin{array}{l}\text { Bobot tongkol } \\
\text { tanpa klobot }\end{array}$ & $286,49^{\mathrm{a}}$ & $300,89^{\mathrm{a}}$ & $305,55^{\mathrm{a}}$
\end{tabular}

Keterangan : Angka yang diikuti huruf sama pada baris menunjukkan tidak beda nyata berdasarkan DMRT taraf $5 \%$.

Jarak tanam yang diujikan tidak memberikan efek dalam bobot tongkol dengan kelobot dan tanpa kelobot (Tabel 7). Menurut Wahyudin et al. (2017), jarak tanam yang lebar akan mengurangi adanya persaingan hara, cahaya, air, sehingga dalam pembentukkan tongkol dan pengisian biji pada tongkol akan lebih optimal. Abuzar et al. (2011) menambahkan bahwa kerapatan tanaman mempengaruhi pertumbuhan dan perkembangan tanaman serta pengaruh produksi karbohidrat. Kerapatan tanaman rendah akan memberikan pertumbuhan varietas jagung yang efektif sehingga sebagian besar hanya memproduksi satu tongkol per tanaman.

\section{Jumlah baris, panjang dan diameter tongkol}

Variabel pengamatan jumlah baris, panjang, dan diameter tongkol menjadi salah satu variabel komponen hasil yang akan menentukan keoptimalan hasil jagung.

Tabel 8 Rata-rata jumlah baris per tongkol, panjang tongkol, dan diameter tongkol pada lima varietas

\begin{tabular}{lrrrrr}
\hline \multirow{2}{*}{ Variabel } & \multicolumn{5}{c}{ Varietas } \\
\cline { 2 - 6 } & ABCD & EFGH & NK6172 & P27 & DK77 \\
\hline $\begin{array}{l}\text { Jumlah } \\
\text { baris per }\end{array}$ & $15,47^{\text {ab }}$ & $14,68^{\mathrm{a}}$ & $16,36^{\mathrm{b}}$ & $16,29^{\mathrm{b}}$ & $\begin{array}{c}15,89 \\
\mathrm{ab}\end{array}$ \\
\hline
\end{tabular}




\begin{tabular}{|c|c|c|c|c|c|}
\hline \multirow{2}{*}{ Variabel } & \multicolumn{5}{|c|}{ Varietas } \\
\hline & ABCD & EFGH & NK6172 & P27 & DK77 \\
\hline $\begin{array}{l}\text { tongkol } \\
\text { (baris) }\end{array}$ & & & & & \\
\hline $\begin{array}{l}\text { Panjang } \\
\text { tongkol } \\
\text { (cm) }\end{array}$ & $20,97^{b}$ & $18,53^{a}$ & $22,02^{b}$ & $21,46^{b}$ & $22,05^{b}$ \\
\hline $\begin{array}{l}\text { Diameter } \\
\text { tongkol } \\
(\mathrm{cm})\end{array}$ & $5,59^{b}$ & $4,76^{a}$ & $5,81^{b}$ & $5,70^{\mathrm{b}}$ & $5,81^{b}$ \\
\hline
\end{tabular}

Keterangan : Angka yang diikuti huruf sama pada baris menunjukkan tidak beda nyata berdasarkan DMRT taraf 5\%.

Panjang dan diameter tongkol varietas $A B C D$, NK6172, P27 dan DK77 memiliki potensi jumlah baris per tongkol, panjang tongkol dan diameter tongkol yang sama pada kondisi lingkungan sama (Tabel 9). Disimpulkan bahwa varietas ABCD hampir memberikan hasil yang sama dengan varietas lain yang diuji, akan tetapi varietas EFGH masih menunjukkan hasil yang rendah dibandingkan varietas lain.

Tabel 9 Rata-rata jumlah pada baris, panjang tongkol, dan diameter tongkol pada jarak tanam

\begin{tabular}{lccc}
\hline \multicolumn{1}{c}{ Variabel } & \multicolumn{3}{c}{ Jarak Tanam } \\
\cline { 2 - 4 } & $70 \times 20 \mathrm{~cm}$ & $75 \times 20 \mathrm{~cm}$ & $75 \times 25 \mathrm{~cm}$ \\
\hline $\begin{array}{l}\text { Jumlah baris per } \\
\text { tongkol (baris) }\end{array}$ & $15,32^{\mathrm{a}}$ & $15,12^{\mathrm{a}}$ & $16,78^{\mathrm{b}}$ \\
$\begin{array}{l}\text { Panjang tongkol } \\
\text { (cm) }\end{array}$ & $20,96^{\mathrm{a}}$ & $20,89^{\mathrm{a}}$ & $21,18^{\mathrm{a}}$ \\
$\begin{array}{l}\text { Diameter tongkol } \\
(\mathrm{cm})\end{array}$ & $5,46^{\mathrm{a}}$ & $5,56^{\mathrm{a}}$ & $5,52^{\mathrm{a}}$ \\
\hline
\end{tabular}

Keterangan : Angka yang diikuti huruf sama pada baris menunjukkan tidak beda nyata berdasarkan DMRT taraf $5 \%$

Berdasarkan Tabel 9, perlakuan jarak tanam yang mampu mengoptimalkan variabel jumlah baris per tongkol yaitu $75 \times 25 \mathrm{~cm}$ (16,78 baris). Berbeda dengan variabel panjang tongkol dan diameter tongkol dimana perlakuan jarak tanam memberi tanggapan sama. Penelitian Sabo (2016) menunjukkan hal yang sama bahwa jarak dalam baris $25 \mathrm{~cm}$ secara signifikan menghasilkan panjang tongkol lebih panjang yang secara statistik sama dengan jarak dalam baris $20 \mathrm{~cm}$, sementara jarak dalam baris $30 \mathrm{~cm}$ memberikan panjang tongkol terkecil.

\section{Bobot biji pipilan kering, bobot 100 biji, dan nilai indeks panen}

Bobot biji pipilan kering, bobot 100 butir biji dan nilai indeks panen menjadi variabel pengamatan komponen hasil dalam tanaman jagung. Perlakuan varietas mampu meningkatkan ketiga variabel ini (Tabel 10). Perlakuan jarak tanam hanya mampu memberikan efek pada variabel pipilan kering saja.

Tabel 10 Rata-rata bobot pipilan kering per plot, bobot 100 butir biji dan nilai indeks panen jagung pada lima varietas

\begin{tabular}{lccccc}
\hline \multirow{2}{*}{ Variabel } & \multicolumn{5}{c}{ Varietas } \\
\cline { 2 - 6 } & ABCD & EFGH & $\begin{array}{c}\text { NK } \\
6172\end{array}$ & P27 & DK77 \\
\hline $\begin{array}{l}\text { Bobot } \\
\text { pipilan } \\
\text { kering per }\end{array}$ & $7,77^{\mathrm{b}}$ & $6,47^{\mathrm{a}}$ & $7,66^{\mathrm{b}}$ & $8,06^{\mathrm{b}}$ & $7,84^{\mathrm{b}}$ \\
\hline
\end{tabular}

\begin{tabular}{|c|c|c|c|c|c|}
\hline \multirow[b]{2}{*}{ Variabel } & \multicolumn{5}{|c|}{ Varietas } \\
\hline & $A B C D$ & EFGH & $\begin{array}{c}\mathrm{NK} \\
6172\end{array}$ & P27 & DK77 \\
\hline plot (kg) & & & & & \\
\hline $\begin{array}{l}\text { Bobot } 100 \\
\text { butir biji } \\
\text { (gram) }\end{array}$ & $36,44^{a}$ & $36,61^{a}$ & $35,22^{a}$ & $40,33^{b}$ & $\underset{\mathrm{ab}}{38,00}$ \\
\hline $\begin{array}{l}\text { Nilai indeks } \\
\text { panen }\end{array}$ & $0,36^{\mathrm{ab}}$ & $0,34^{\mathrm{a}}$ & $0,37^{b}$ & $0,38^{b c}$ & $0,41^{\mathrm{c}}$ \\
\hline
\end{tabular}

Keterangan : Angka yang diikuti huruf sama pada baris menunjukkan tidak beda nyata berdasarkan DMRTtaraf $5 \%$.

Varietas hibrida jagung yang diterapkan mampu meningkatkan bobot pipilan kering per plot, bobot 100 butir biji dan nilai indeks panen (Tabel 10). Bobot pipilan kering per plot yang tinggi menunjukkan pengisian biji optimal. Hal ini didukung oleh Ukonze (2016) bahwa hasil berat tongkol tinggi mungkin disebabkan oleh jumlah biji pada setiap tongkol yang diukur. Pengamatan bobot 100 butir biji menandakan besarnya endosperm dalam biji. Variabel selanjutnya yaitu indeks panen. Semakin tinggi indeks panen jagung menunjukkan bahwa partisi fotosintat di tajuk banyak ditranslokasikan ke bagian biji (Efendi dan Suwardi 2010). Data tabel 10 menunjukkan bahwa nilai indeks panen berkisar 0,36-0,41 dimana varietas DK77 memiliki nilai indeks panen tertinggi yaitu 0,41 . Terlihat bahwa nilai indeks panen varietas $A B C D$ dan $E F G H$ masih rendah dari varietas lain yang diujikan. Hal ini menandakan kurangnya efisiensi tanaman dalam mentranslokasikan fotosintat ke bagian biji (Efendi dan Suwardi 2010).

Tabel 11 Rata-rata bobot pipilan kering per plot, bobot 100 butir biji dan nilai indeks panen jagung pada jarak tanam

\begin{tabular}{lccc}
\hline \multicolumn{1}{c}{ Variabel } & \multicolumn{3}{c}{ Jarak Tanam } \\
\cline { 2 - 4 } & $70 \times 20 \mathrm{~cm}$ & $75 \times 20 \mathrm{~cm}$ & $75 \times 25 \mathrm{~cm}$ \\
\hline Bobot pipilan & $6,77^{\mathrm{a}}$ & $7,50^{\mathrm{b}}$ & $8,40^{\mathrm{c}}$ \\
kering per plot (kg) & & $36,40^{\mathrm{a}}$ & $38,73^{\mathrm{a}}$ \\
Bobot 100 butir biji & $36,83^{\mathrm{a}}$ & $0,36^{\mathrm{a}}$ & $0,39^{\mathrm{b}}$ \\
(gram) & $0,36^{\mathrm{a}}$ & &
\end{tabular}

Keterangan : Angka yang diikuti huruf sama pada baris menunjukkan tidak beda nyata berdasarkan DMRT taraf $5 \%$

Berdasarkan Tabel 12, perlakuan jarak tanam hanya mampu meningkatkan bobot pipilan kering per plot dan nilai indeks panen saja. Nilai indeks panen pada perlakuan jarak tanam $75 \times 25 \mathrm{~cm}$ memiliki nilai tertinggi $(0,39)$. Menurut Ikhwani et al. (2013), penerapan jarak tanam yang efektif pada dasarnya bertujuan untuk memberikan kemungkinan tanaman tumbuh dengan baik tanpa mengalami banyak persaingan dalam hal ketersediaan air, unsur-unsur hara, dan cahaya matahari secara optimal untuk proses fotosintesis. Khumar (2008) menambahkan bahwa ketersediaan unsur hara optimal seperti nitrogen dan fosfor yang diserap tanaman akan dialokasikan dalam biji dan meningkatkan laju pertumbuhan tanaman.

\section{Hasil panen ton hektar ${ }^{-1}$}

Hasil panen merupakan target utama pada produksi suatu tanaman. Perlakuan varietas jagung hibrida 
mampu meningkatkan hasil panen ton hektar ${ }^{-1}$. Jarak tanam juga mampu meningkatkan hasil panen ton hektar $^{-1}$.

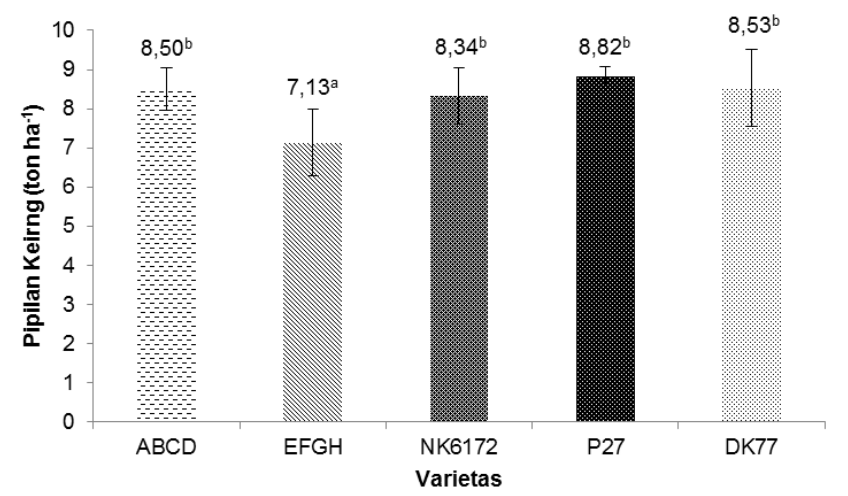

Gambar 1 Hasil Panen Lima Varietas Jagung Hibrida

Hasil panen pipilan kering tertinggi pada varietas P27 (8,82 ton ha $\left.^{-1}\right)$ yang memiliki rentan sama pada varietas ABCD, NK6172, dan DK77. Sutresno et al. (2016) menyatakan bahwa hibrida Pioneer dapat lebih menyesuaikan diri (beradaptasi) pada lingkungan tumbuh dengan teknologi budidaya yang memadai dengan rata-rata bobot biji kering pipil tertinggi setara dengan 13,03 ton ha ${ }^{-1}$. Gambar 1 menunjukkan bahwa rata-rata hasil panen pipilan kering terendah yaitu pada varietas $\mathrm{EFGH}$ yaitu 7,13 ton $\mathrm{ha}^{-1}$, sedangkan varietas ABCD memiliki hasil panen hampir sama dengan varietas lain $\left(8,50\right.$ ton ha $\left.{ }^{-1}\right)$. Marliah et al. (2010) menyatakan bahwa setiap varietas masing-masing mempunyai susunan genetik yang tidak sama dan kemampuan varietas itu sendiri dalam beradaptasi dengan lingkungan tumbuhnya sehingga tetap menghasilkan pertumbuhan yang baik dan hasil yang maksimal. Meskipun secara genetik varietas lain mempunyai potensi produksi yang baik, tetapi karena masih dalam tahap adaptasi, produksinya lebih rendah daripada seharusnya.

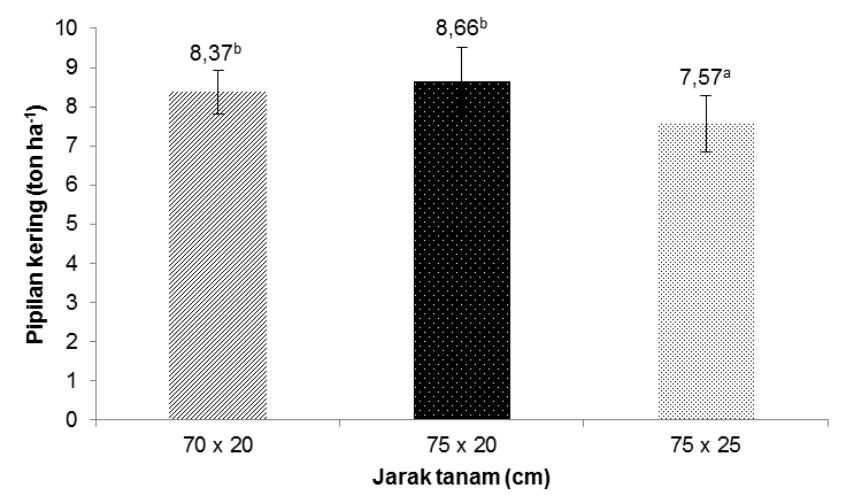

Gambar 2 Hasil Panen pada Jarak Tanam Berbeda

Sharifi et al. (2009) menyatakan bahwa secara umum hasil panen satu tanaman jagung menurun seiring dengan bertambahnya populasi tanaman. Namun pada Gambar 2 menunjukkan bahwa hasil tetinggi pada jarak tanam $75 \times 20 \mathrm{~cm}\left(8,66\right.$ ton ha $\left.{ }^{-1}\right)$ dan jarak tanam $70 \times 20 \mathrm{~cm}\left(8,37\right.$ ton ha $\left.^{-1}\right)$ kemudian terendah $75 \times 25 \mathrm{~cm}\left(7,57\right.$ ton $\left.\mathrm{ha}^{-1}\right)$. Hal ini diduga karena jarak tanam $75 \times 20 \mathrm{~cm}$ memiliki populasi lebih banyak dengan jarak antar baris sama dengan $75 \times 25$ $\mathrm{cm}$, sehingga memeberikan hasil panen lebih tinggi. Menurut responden pada penelitian Biba (2015), jarak tanam $75 \times 20 \mathrm{~cm}$ memiliki kelebihan yaitu menghasilkan populasi tanaman lebih banyak, sedangkan ukuran hampir sama dengan jarak tanam yang lebih lebar sehingga produktivitasnya lebih tinggi.

Perlakuan jarak tanam 75 × $25 \mathrm{~cm}$ memiliki hasil panen pipilan kering terendah diduga karena pada jarak tanam tersebut jumlah populasi sedikit dan terdapat banyak gulma. Hal ini didukung oleh Yulisma (2011) jarak tanam lebar atau jarang akan memberi peluang berkembangnya gulma dan jumlah populasi tanaman rendah sehingga cahaya matahari dan unsur hara yang diserap tanaman akan berkurang karena sebagian cahaya akan jatuh ke permukaan tanah dan unsur hara akan hilang karena penguapan dan pencucian.

\section{KESIMPULAN}

Berdasarkan hasil penelitian dapat diambil kesimpulan bahwa:

1. Perlakuan jarak tanam $75 \times 20 \mathrm{~cm}$ lebih efektif dalam mengoptimalkan daya hasil jagung hibrida $\left(8,66\right.$ ton ha $\left.^{-1}\right)$ dibanding dengan perlakuan jarak tanam lain.

2. Perlakuan varietas jagung hibrida $A B C D$ lebih mampu mengoptimalkan daya hasil dibandingkan dengan varietas EFGH $\left(8,50\right.$ ton ha $\left.{ }^{-1}\right)$, sedangkan varietas ABCD, NK6172, P27, dan DK77 memiliki potensi daya hasil sama.

3. Tidak terdapat interaksi antara varietas dan jarakt tanam kecuali pada tinggi tanaman, bobot segar brangkasan, dan bobot kering brangkasan.

\section{SARAN}

Berdasarkan penelitian yang telah dilakukan dapat diberikan saran yaitu penerapan jarak tanam $75 \times 20$ $\mathrm{cm}$ dan penggunaan varietas ABCD berpotensi mengoptimalkan daya hasil jagung hibrida dibandingkan dengan varietas EFGH serta perlu adanya penelitian lanjutan mengenai jarak tanam dibawah $70 \times 20 \mathrm{~cm}$ dan di atas $75 \times 25 \mathrm{~cm}$ dengan penambahan perlakuan dosis pupuk untuk lebih meningkatkan komponen hasil jagung hibrida.

\section{UCAPAN TERIMA KASIH}

Ucapan terima kasih diberikan untuk PT Advanta Seed Indonesia atas kerjasama dan bantuan fasilitas yang telah diberikan selama pelaksanaan penelitian penulis yang berjudul "Jarak Tanam Berbeda pada Uji Daya Hasil Lima Varietas Jagung Hibrida”.

\section{DAFTAR PUSTAKA}

[BPS] Badan Pusat Statistik. 2016. Statistik dasar tanaman pangan. URL: https://www.bps.go.id/Subjek/view/id/53. Diakses tanggal 6 Mei 2017.

Abuzar MR, Sadozai GU, Baloch MS et al. 2011. Effect of plant population densities on yield of maize. $J$ Anim Plant Sci 2(4): 692-695. 
Biba MA. 2015. Pengaruh jarak tanam dan varietas jagung hibrida terhadap pendapatan petani. Prosiding Seminar Nasional Serealia. Balai Penelitian Tanaman Serealia. Sulawesi Selatan.

Biswas M, Rahman AHMM, Ahmed F. 2014. Effect of variety and planting geometry on the growth and yield of hybrid maize. J Agric Environ Sci 3(2): $27-$ 32.

Desyanto E, Herman BS. 2014. Pengaruh jarak tanam terhadap pertumbuhan hijauan hasil buah jagung (Zea mays L.) pada varietas bisi dan pioneer di lahan marginal. J Agro ${ }^{\text {UPY }}$ 5(2): 50-66.

Efendi R, Suwardi. 2010. Respon tanaman jagung hibrida terhadap tingkat takaran pemberian nitrogen dan kepadatan populasi. Prosiding Pekan Serealia Nasional.

Enujeke EC. 2013. Effects of variety and spacing on growth characters of hybrid maize. Asian J Agric Rural Dev 3(5): 296-310.

Hamidi A, Khodabandehb N, Mohammadynasabe AD. 2010. Plant density and nitrogen effects on some traits of maize (Zea mays L.). J Plant Ecophysiol. 2: 47-52.

Ikhwani GR, Pratiwi, Paturrohman et al. 2013. Peningkatan produktivitas padi melalui penerapan jarak tanam jajar legowo. Puslitbang Tanaman Pangan Bogor.

Jafri. 2011. Tanggap pertumbuhan beberapa varietas jagung terhadap sistem tanam lurus dan zigzag di lahan gambut Kalimantan Barat. Seminar Nasional Serealia 2011. Balai Pengkajian Teknologi Pertanian Kalimantan Barat.

Jiang W, Wang K, Wu Q et al. 2013. Effects of narrow plant spacing on root distribution and physiological nitrogen use efficiency in summer maize. The Crop Journal 1: 77-83.

Khan W, Singh V, Sagar A et al. 2017. Response of phosphorus application on growth and yield attributes of sweet corn (Zea mays L. Saccharata) varieties. J Pharmacogn Phytochem 6(5): 21442146.

Khumar A. 2008. Growth, yield and water use efficiency of different maize (Zea mays L.) based cropping systems under varying planting methods and irrigation levels. India J Agric Sci 78(3): 244-247.

Marliah A, Jumini, Jamilah. 2010. Pengaruh jarak tanam antar barisan pada sistem tumpangsari beberapa varietas jagung manis dengan kacang merah terhadap pertumbuhan dan hasil. J Agrista 14(1): 30-38.

Putri HA. 2011. Pengaruh pemberian beberapa konsentrasi pupuk organik cair lengkap (POCL) bio sugih terhadap pertumbuhan dan hasil tanaman jagung manis (Zea mays saccharata Sturt.). Skripsi. Fakultas Pertanian. Universitas Andalas. Padang.

Sabo MU, Wailare MA, Aliyu M et al. 2016. Effect of variety and spacing on growth and yield of maize (Zea mays L.) in Bauchi State, Nigeria. Int J Plant Soil Sci 9(6): 1-6.
Sharifi RS, Sedghi M, Gholipouri A. 2009. Effect of population density on yield and yield attributes of maize hybrids. Res J Bio Sci 4(4): 375-379.

Sutresno IW, Aryana IGPM, Gunartha IGEP. 2016. Evaluasi genotipe jagung (Zea mays L.) unggul pada lingkungan tumbuh dengan perbaikan teknologi budidaya. Seminar Nasional Inovasi IPTEKS Perguruan Tinggi untuk Meningkatkan Kesejahteraan Masyarakat. Denpasar. Bali.

Ukonze, Adimonye J, Akor et al. 2016. Comparative analysis of three different spacing on the performance and yield of late maize cultivation in Etche local government area of River State, Nigeria. Afr J Agric Res 11(13): 1187-1193.

Wahyudin A, Ruminta, Bachtiar DC. 2015. Pengaruh jarak tanam berbeda pada berbagai dosis pupuk organik terhadap pertumbuhan dan hasil jagung hibrida P-12 di Jatinagor. J Kultivasi 14(1): 1-8.

Wahyudin A, Yuwariah Y, Wicaksono FY, Bajri RAG. 2017. Respons jagung (Zea mays L.) akibat jarak tanam pada sistem tanam legowo (2:1) dan berbagai dosis pupuk nitrogen pada tanah inceptisol Jatinagor. J Kultivasi 16(3): 507-513.

Yulisma. 2011. Pertumbuhan dan hasil beberapa varietas jagung pada berbagai jarak tanam. Penelitian pertanian tanaman pangan 30(3): 196203. 